\title{
O RISO COMO REFLEXÃO FILOSÓFICA EM LUCIANO $^{1}$
}

\author{
Rafael Guimarães Tavares da Silva*
}

Recebido em: 26/11/2018

Aprovado em: 21/01/2019

RESUMO: A obra de Luciano é amplamente conhecida por sua dimensão satírica, embora seu aspecto filosófico - nem sempre reconhecido por seus estudiosos - seja imprescindível para que se compreendam suas estratégias cômicas. O objetivo do presente texto é buscar e analisar os fundamentos do riso nesse autor - sobretudo a partir de seus Diálogos dos mortos -, a fim de oferecer uma nova compreensão das dificuldades frequentemente associadas a essa obra. Para isso, sugeriremos a dimensão filosófica do riso luciânico, tal como indica seu diálogo com a reflexão de filósofos sobre o tema (principalmente na vertente platônica presente no Filebo). Além disso, desenvolveremos considerações sobre certos "problemas" específicos suscitados pela obra (tal como o silêncio de Odisseu), sugerindo haver conexões entre eles e nossa interpretação mais geral. Desse modo, pretendemos reforçar a corrente de intérpretes que enxerga e defende a dimensão filosófica da obra de Luciano, em contraposição ao que é o entendimento tradicional acerca desse autor.

PALAVRAS-CHAVE: Luciano; riso; Diálogos dos Mortos; filosofia.

\section{LAUGHTER AS PHILOSOPHICAL REFLECTION IN LUCLAN}

* Doutorando do Programa de PósGraduação em Estudos Literários, Universidade Federal de Minas Gerais. Bolsista da Coordenação de Aperfeiçoamento de Pessoal de Nível Superior, CAPES. gts.rafa@hotmail.com

\begin{abstract}
Lucian's work is widely known for his satirical dimension, even though his philosophical aspect - not always well recognized by scholarship - is indispensable to understand his comic strategies. This text's aim is to search and analyze the foundation of laughter in his Dialogues of the dead, in order to provide a new comprehension of the difficulties often associated with this work. For this, we will suggest the philosophical dimension of Lucianic laughter, as it is suggested by his
\end{abstract}

\footnotetext{
${ }^{1}$ Uma versão prévia - parcial e reduzida - da interpretação aqui proposta havia sido anteriormente formulada em SILVA (2015, p. 95-109).
}

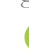


dialogue with some philosophers' reflections upon this theme (mainly in the Platonic strand, as it is presented in one of Philebus' passages). Besides, we will develop considerations about some specific "problems" aroused by this work (as Odysseus' silence), suggesting the existence of connections between them and our more general interpretation. In this way, we intend to reinforce the strand of interpreters who see and defend the philosophical dimension of Lucian's work, in contrast to the traditional understanding about this author.

KEYWORDS: Lucian; laughter; Dialogues of the Dead; philosophy.

\section{I}

A quilo que atualmente chamamos de literatura se mantém - ainda hoje - como um espaço privilegiado para a reflexão crítica sobre a sociedade e a cultura. Tal como sugerido por um autor que trabalha nas fronteiras entre os textos literários, filosóficos e científicos, "o espaço da literatura não é somente o de uma fiçãa instituída, mas também o de uma instituição fictícia, a qual, em princípio, permite dizer tudo." (Derrida, 2014, p. 49). Ainda que o advento dessa concepção moderna de literatura remonte às reflexões desenvolvidas com os Frübromantiker, isto é, com os autores do Primeiro Romantismo Alemão, ${ }^{2}$ e coincida com o advento de discursos democráticos e republicanos na modernidade ocidental, ${ }^{3}$ acreditamos que alguns autores da Antiguidade tenham feito obras - monstruosamente transgressoras das regras de poética clássica, cabe ressaltar - que apontam os desenvolvimentos futuros dos conceitos modernos de literatura e fiçãa.

Nossos pressupostos de base para sugerirmos tal entendimento são os seguintes: i) a poética clássica é preponderantemente uma poética de classe; ii) em momentos de conturbação social, durante os quais uma nova classe surge e se fortalece (em detrimento de classes mais tradicionais), novos gêneros poéticos são desenvolvidos - a partir de processos como a contaminatio e a hibridização genérica, por exemplo -, vindo a questionar os gêneros tradicionalmente prescritos pela poética clássica. Ora, o romance antigo surge justamente em um período de conturbação social do Império Romano e algo análogo poderia ser

\footnotetext{
${ }^{2}$ Para mais detalhes, cf. Lacoue-Labarthe; Nancy, 1978; Medeiros, 2018.

${ }^{3}$ Ainda que concordemos com o que afirma Derrida $(2015$, p. 58) sobre o advento da noção moderna de literatura, vamos modalizar sua asserção no que diz respeito à cultura greco-latina no seguinte trecho: “O termo 'literatura' é uma invenção muito recente. Anteriormente, a escrita não era indispensável para a poesia ou as belas-letras, tampouco a propriedade autoral ou mesmo a assinatura individual. Esse é um enorme problema, difícil de ser abordado aqui. O conjunto de leis ou convenções que estabeleceu o que se chama de literatura na modernidade não era indispensável para que obras poéticas circulassem. Não me parece que a poesia grega ou latina, as obras discursivas não europeias, pertençam à literatura stricto sensu. Podemos dizer isso sem reduzir absolutamente o respeito ou a admiração que merecem. [...] O princípio (enfatizo que é um princípio) de 'poder dizer tudo', a garantia socio-jurídico-política concedida 'em princípio' à literatura é algo que não fazia muito sentido, não o mesmo sentido, na cultura greco-latina e a fortiori em uma cultura não ocidental.” (Derrida, 2014, p. 58).
} 
defendido também para se explicar a ascensão do romance moderno burguês na Inglaterra do século XVIII. ${ }^{4}$

Nesse sentido, estamos de acordo com o que afirma Jacyntho Lins Brandão, na introdução a seu incontornável estudo sobre um importante autor coetâneo da "ascensão do romance" na Antiguidade, Luciano de Samósata:

[O] lógos luciânico, como uma sorte de outro dos discursos consagrados, sérios e verdadeiros, nas brechas dos quais, entretanto, encontra seu lugar, só pode ser definido como ficcional. No fundo, o que faz da obra de Luciano um objeto permanente de interesse é a possibilidade de acompanhar como se processa nela uma autêntica descoberta da fição, que consequentemente define um estatuto não só para o discurso, como também para o escritor e o leitor. [...] [D]esejo ressaltar como a ficção, entendida como um discurso de alteridade, justamente por isso se presta à crítica aos mais diversos aspectos da cultura e da sociedade; portanto, falar de ficção supõe sempre falar de sociedade e cultura [...]. (Brandão, 2001, p. 27).

Levando isso em conta, acreditamos poder tratar também da literatura de Luciano como esse espaço privilegiado para a reflexão crítica, fazendo-o sem qualquer anacronismo, ainda que ele seja um autor antigo e esteja, a princípio, excluído das considerações que Derrida (2014, p. 58) propõe sobre a função crítico-política da literatura na modernidade ocidental. A fim de explicitar isso, pretendemos nos concentrar numa obra específica - qual seja, os Diálogos dos mortos -, posto que seu viés crítico perante a cultura de sua época nos parece emblemático do modus operandi desse autor: deslocando a perspectiva naturalizada de seu público, ao adotar a visão dos que morreram e se encontram no submundo, Luciano delineia uma série de diálogos críticos sobre a vida humana, naquilo que suas instituições apresentam de mais paradoxal perante a incontornável condição dos mortais.

O procedimento de deslocar o leitor de sua perspectiva confortável é típico desse autor - tão afeito à condição de estrangeiro como forma de posicionamento crítico aos contrassensos socialmente naturalizados - , sendo retomado em muitas de suas obras: seja em seu elogio da condição de estrangeiro (Herm. 22-24; 31; 34; Zeux. 1; 10), seja nos deslocamentos de personagens para espaços que não lhes são naturais (Cont; Icar; VH).

\footnotetext{
${ }^{4}$ Essa comparação entre os dois fenômenos foi sugerida por uma apresentação de Júlia Batista Castilho de Avellar (2018) e será desenvolvida por ela em um artigo futuro. Para detalhes sobre a "invenção do romance" na Antiguidade - incluindo os problemas de poética e de denominação envolvidos na questão - cf. Brandão, 2005. Para detalhes sobre a "ascensão do romance" na modernidade, cf. Watt, 2007. Embora concordemos com as teses principais de Ian Watt, somos obrigados a destacar aqui a crítica de Nabil Araújo (2015a), ao propor uma delimitação mais precisa daquilo que teria "ascendido" na Inglaterra do século XVIII: não o romance moderno tout court, como Watt parece sugerir, mas sim o romance moderno burguês - do contrário, como compreender obras como Dom Quixote de Cervantes e Gargântua de Rabelais, por exemplo? Para detalhes dessa polêmica, cf. Araújo, 2015a, p. 139-56; Fernandes; Alves; Gil, 2015, p. 11-12; Araújo, 2015b, p. 118-24.
} 
Ainda que não seja possível afirmar peremptoriamente que Luciano tenha inaugurado esse deslocamento de perspectiva para avançar uma crítica da vida humana - posto que algo parecido já se encontra presente no próprio Homero, na figura de Odisseu, o xénos por excelência, e mesmo em sua vertente cômica com Aristófanes (em $A v$. e Ra., por exemplo) -, o fato é que o expediente compõe um dos elementos fundamentais de sua "poética do hipocentauro" (para nos valermos aqui da expressão cunhada por Brandão). Sequer o recurso à perspectiva dos mortos como viés para uma crítica da vida mortal é exclusividade de Luciano, já que algo dessa ordem se dá em Homero (em $O d$.11.489-91, na célebre passagem em que Aquiles, perante a miséria de sua situação no post-mortem, lamenta ter morrido heroicamente tão jovem), mas é preciso reconhecer a importância que adquire na obra desse autor, a ponto de se revelar fundamental para a constituição do que se tornou uma espécie de subgênero literário: para além dos inúmeros "diálogos dos mortos" que floresceram na história da literatura, de Fénelon a Voltaire, ${ }^{5}$ o emprego da perspectiva dos mortos com o propósito de satirizar as mazelas das instituições sociais foi retomado com proveito várias vezes por importantes escritores e artistas na modernidade, como em obras célebres de Dostoiévski (Bobók) e Machado de Assis (Memórias póstumas de Brás Cubas). No limite, até mesmo um romance inclassificável como o Ulysses de Joyce estaria em diálogo com essa tradição. ${ }^{6}$

Em que pese a importância literária dessa obra de Luciano, contudo, sua interpretação permanece profundamente controversa entre os estudiosos do assunto. Nosso texto buscará analisar os fundamentos do riso nesse autor, a fim de oferecer uma nova compreensão das dificuldades frequentemente associadas a sua obra.

\section{II}

Os Diálogos dos mortos estão entre as obras luciânicas que receberam as interpretações mais surpreendentemente divergentes por parte da crítica (Brandão, 2001, p. 12). Enquanto Bompaire (1958, p. 561), em seu estudo enciclopédico, defende que esses diálogos seriam a transposição de certas formas retóricas e literárias tradicionais para uma mise en scène no submundo, Baldwin (1961, p. 201) defende que o propósito de Luciano "é estabelecer um programa de crítica social inconfundivelmente associado com os cínicos". Numa abordagem

\footnotetext{
${ }^{5}$ Para detalhes disso, sobretudo no século XVIII francês, cf. Andries, 2013.

${ }^{6}$ Em comunicação apresentada no XX Congresso da SBEC, Jorge Cunha Conrado de Miranda (2015) sugeriu que o Ulysses de James Joyce poderia ser lido como uma execução do mito de Er - baseado na teoria da metempsicose -, tal como sugerido por Sócrates no final da República de Platão, ao afirmar que "a alma de Odisseu, a quem a sorte fixara o último lugar, [...] despojada do desejo pela honra devido a lembranças das fadigas passadas, girou longamente à procura da tranquila condição de um homem privado [andròs idiótou]; a custo achou uma que jazia num canto, desdenhada pelos outros; e, ao percebê-la, declarou que não teria agido de outro modo, ainda que a sorte o tivesse chamado em primeiro lugar e, alegre, escolheu-a.” (Rep. 620c-d, trad. Jacó Guinsburg). O próprio Luciano parece refletir entendimento análogo em Necyomantia (4; 21) e Hermotimus (83), em passagens onde se faz um elogio da "vida dos homens comuns" [ho tôn idiōtôn ... bios $]$.
} 
diferente dessa obra, Relihan (1987, p. 189-92) acredita que o personagem de Menipo, apresentado como herói, seria o responsável por fornecer a coerência ao todo. Isso é o oposto do que Branham (1989, p. 143) afirma sobre os diálogos menores em geral, posto que, para ele, "em vez de um único texto unificado por enredo ou argumento, existe uma série de momentos destacáveis, como um livro de epigramas ou poemas curtos, mas sem relação detectável entre si." A dificuldade de se afirmar o que quer que seja com alguma certeza sobre Luciano e sua obra foi admitida por todos esses estudiosos e aparece claramente em suas divergências críticas. No presente texto, tentaremos descobrir a razão para tal embaraço por meio de uma análise tanto do que parece constituir a fonte de riso desses diálogos quanto de suas estratégias cômicas.

Primeiramente, é importante ter em mente que "o riso é essencialmente comunal" (Branham, 1989, p. 163) e existe, portanto, apenas quando certos valores são compartilhados por uma comunidade. Como defendido pelo elucidativo estudo de Bergson,

o riso deve ser algo desse gênero, uma espécie de gesto social. Pelo temor que inspira, ele reprime as excentricidades, mantém constantemente alerta e em contato recíproco certas atividades de ordem acessória que arriscariam se isolar e adormecer, flexibiliza enfim tudo o que pode permanecer de rigidez mecânica na superfície do corpo social. (Bergson, 1938, p. 20-21, trad. nossa).

Esse pressuposto é especialmente importante quando consideramos algo que subjaz a cada um dos Diálogos dos mortos. Tal como ilustrado pelas últimas palavras de Menipo no último diálogo (segundo a ordem da recensão $\Gamma$ ): "No Hades reina a igualdade e todos são parecidos". ${ }^{8}$ A condição extrema compartilhada no submundo por todo personagem outrora mortal é sua igualdade (isotimía). Esse é o valor que predomina na maior parte desses diálogos, tal como afirmado abertamente por alguns dos próprios personagens. ${ }^{9}$ Segundo um estudioso da obra de Luciano:

Se na esfera da existência terrena dos homens a consecução do ideal da isotimia apresenta-se sob o signo da impossibilidade, de um ponto de vista mais amplo revela-se factível, ainda que num alótopo: o mundo dos mortos. A distância que separa o reino de Zeus do

\footnotetext{
${ }^{7}$ A numeração dos diálogos aqui apresentada segue a tradição manuscrita dominante, que preserva em $\Gamma$ o mais importante representante da família $\gamma$. Adicionaremos entre chaves também o número de referência tradicional de cada diálogo. A ordem apresentada, contudo, não pode reivindicar que seja a mesma de Luciano (se é que o autor realmente estabeleceu uma ordem específica). Para mais detalhes, cf. o texto da introdução de McLeod à sua edição (Lucian, 1961, p. ix-xi).

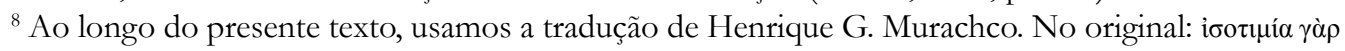

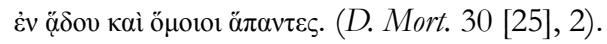

${ }^{9}$ Cf. Brandão, 1996, p. 29. Vale notar que o mesmo princípio vigora também em outras obras luciânicas que retratam o mundo dos mortos, como, por exemplo, nas seguintes passagens: Cataplus 22; Menippus seu Necyomanthia 15-21.
} 
reino de Crono repete-se, de uma perspectiva qualitativo-espacial, entre os reinos de Zeus e do Hades. Enquanto a primeira oposição parte da nostalgia de uma idade de ouro perdida, a segunda tem em vista um espaço de alteridade a ser conquistado, projetando-se para o futuro. Não se trata, evidentemente, de nenhuma esperança escatológica de felicidade para os pobres, com a reversão das amarguras experimentadas na vida presente - como prometia, dentre outras religiões de mistérios, o cristianismo nascente - mas de uma visão mais pessimista, mais desesperada. Como a idade de ouro, o Hades de Luciano é ficcional. (Brandão, 2001, p. 160).

Mas se nessa ficção todo mundo é igual e compartilha as mesmas honras, quais atitudes poderiam se revelar risíveis e por quê? Como a aplicação da ideia de Bergson ao presente caso torna evidente, a resposta é: qualquer atitude que possa tentar subverter o principal valor do submundo, ou seja, a igualdade. E isso se dá principalmente por causa de "memórias da vida lá de cima", tal como expressas por algumas das lamúrias dos personagens. Com relação a isso, a mensagem de Diógenes para Menipo (em D. Mort. 1 [1], 1) é elucidativa, na medida em que afirma o seguinte:

Aqui, no entanto, não cessarás de rir com segurança, como eu estou fazendo agora. Sobretudo porque tu vês os ricos, os sátrapas, os tiranos, agora rebaixados e insignificantes, reconhecidos apenas pela lamentação; isto é, que são uns poltrões e ignóbeis, enquanto ficam recordando das coisas lá de cima. ${ }^{10}$

Então a memória da condição perdida (tal como expressa pela palavra memnèmenoi) e, apesar da irreparabilidade de tal perda, a expressão do desejo de reconquistá-la (tal como pode ser entendida na lamentação desses mortos, oimōgês) são modos de tentar ignorar ou se contrapor à igualdade do submundo. Esse primeiro diálogo ainda oferece uma lista dos tipos mais propícios a exprimir esse comportamento ridículo: sátrapas, tiranos, homens ricos, filósofos, pessoas belas e fortes. ${ }^{11}$ Nesse sentido, o primeiro diálogo funciona praticamente como um proêmio para toda a série, exibindo os principais objetos de riso aos olhos dessa defunta sociedade. O que é risível, contudo, não é tanto a busca por essas coisas na terra

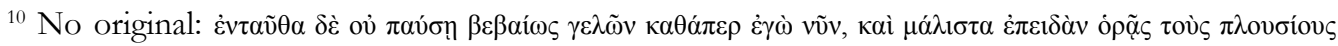

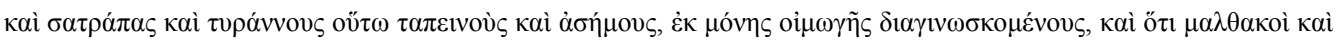

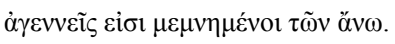

${ }^{11}$ Segundo Brandão (1996, p. 34), existe uma gradação, começando com a posse de riqueza material, mas indo até a posse de vantagens físicas, sociais e intelectuais nos tipos ridicularizados pelos Diálogos dos mortos. Essa gradação parece servir a propósitos cômicos, na medida em que implica o rebaixamento de valores tradicionalmente elevados. Outras obras luciânicas que ridicularizam a vaidade da força física, da riqueza e do conhecimento, da perspectiva do post-mortem, são, por exemplo: Cont. 9-15; Nec. 12.
} 
(embora do ponto de vista cínico, tal como representado por Diógenes e Menipo, ${ }^{12}$ isso também seja ridículo), mas permanecer desejando essas coisas no post-mortem.

Aqui pode ser interessante evocar a relação proposta pelo Sócrates de Platão (Phil. 48c-d), entre o ridículo (tò gelôion) e a ignorância de si. ${ }^{13}$ A nosso ver, essa relação não é de pouca monta para a compreensão do riso de Luciano nos Diálogos dos mortos e em suas outras obras localizadas no submundo. A incapacidade que todos os personagens anteriormente ricos, belos, poderosos ou reputados sábios demonstram em reconhecer sua condição atual de igualdade com relação aos demais parece ser a principal fonte do cômico nessas obras. As palavras de Sócrates na sequência da passagem supracitada são empregadas para dividir em três as formas pelas quais alguém pode ser afetado pela falta de autoconhecimento: com relação à riqueza (khrémata), qualidades físicas (eîdos) e virtudes (aretôn). Em seguida, ele procede à definição dos diferentes tipos de efeito da ignorância de si. Segundo ele (Phil. 49b-c), ser poderoso (dunatós) ou sem poder (adúnatos) é o que pode tornar a ignorância (ágnoia) sobre a própria condição algo odiável e infame (ekbthrá te kaì aiskhrâ) ou naturalmente ridículo (tến tôn geloîon ... táxin te kaì phúsin). No submundo, devido à ausência de poder ou qualquer tipo de distinção (as sombras são frequentemente chamadas de asémoı), segundo a sugestão platônica, a única possibilidade para a ignorância de si é ser ridícula.

Da mesma forma, a menção direta, tanto nos diálogos platônicos quanto nos luciânicos (D. Mort. 3 [2], 2), desse antigo preceito, tal como inscrito no Oráculo de Delfos - "conhece-te a ti mesmo" (gnôthi sautòn) -, reforça a percepção de que o cômico aqui está relacionado com a ignorância, isto é, não com qualquer tipo de ignorância, mas com a ignorância de si. Uma leitura atenta dos Diálogos dos mortos poderia destacar algumas passagens em que não saber de algo, ou antes, não sabê-lo mais (devido ao esquecimento), é até desejável. ${ }^{14}$ Mas é preciso reconhecer a própria condição, conhecer-se a si mesmo e esquecer o que foi irremediavelmente perdido. Mais uma vez, a memória da vida passada e a relutância em deixá-la passar são formas de ignorância de si e, consequentemente, objetos do riso.

\footnotetext{
12 Tendemos a concordar com o que é defendido por Bompaire (1958, p. 183, n. 6), para quem os papéis de Menipo e Diógenes nas obras de Luciano são confundidos e frequentemente indiferenciados. Relihan (1987, p. 191), contudo, defende que Menipo é usado de formas distintas das de outros cínicos nos Diálogos dos mortos.

${ }^{13} \mathrm{Na}$ tradução de Fernando Muniz, Sócrates afirma que o ridículo envolve "uma experiência oposta ao que é dito pela inscrição de Delfos", ao que Protarco completa dizendo: "Estás falando do 'conhecete a ti mesmo', Sócrates?" (tò 'gnôthi sautòn' légeis, ô Sốkrates?).

${ }^{14}$ Cf. D. Mort. 13 [13], 6. Ao fim desse diálogo, Diógenes dá o seguinte conselho a Alexandre: "bebe pelo menos, com a boca bem aberta, da água do Letes; bebe de novo, bebe muitas vezes", a fim de esquecer suas posses mundanas e "cessar de [s]e afligir por causa dos bens de Aristóteles". No

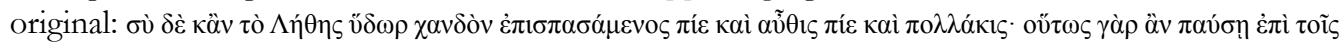

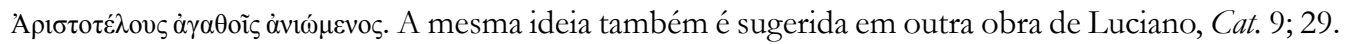


Esse mesmo princípio pode ser aplicado ao longo de todos os Diálogos dos mortos para mostrar quão profundamente até mesmo a mais aparentemente superficial dessas interações está relacionada com essa forma platônica de cômico, na qual a ignorância é o principal objeto do ridículo. Levando-se em conta as atitudes que os personagens apresentam uns em relação aos outros, podemos encontrar nesses diálogos duas principais tendências típicas: uma zombaria da incapacidade de alguém em "conhecer-se a si mesmo" e uma disputa agônica, onde um verdadeiro tour de force é estabelecido entre os interlocutores. ${ }^{15}$

\section{III}

A maior parte do riso nos Diálogos dos mortos é provocada onde a zombaria parece prevalecer por meio da demonstração da dificuldade de alguns personagens de se conhecerem a si mesmos bem o bastante para aceitar uma situação inevitável, isto é, inevitável diante das circunstâncias presentes. Como a inevitabilidade de tal situação nos Diálogos dos mortos é a própria morte, a zombaria é ainda mais aguda pela mise en scène do diálogo inteiramente concentrada no submundo e em suas estranhas "leis físicas". ${ }^{16}$

O humor de tais situações é tornado evidente pelo conflito suscitado por quem deseja o oposto a algo que se revela inevitável, tal como podemos sugerir por meio das antíteses contidas no enredo dos seguintes diálogos: 2 [22], onde Caronte tenta fazer o miserável Menipo pagar a taxa do barqueiro; 3 [2], onde os mortos Creso, Midas e Sardanápalo, "desassinalados" (asếmoi), se recusam a aceitar a perda de bens que outrora tiveram em vida; 4 [21], onde Sócrates é depreciado por ter apresentado temor quando encarado com a morte (apesar de seu proverbial destemor de morrer); 5 [18], onde Menipo parece surpreso que os aqueus tenham supervalorizado Helena, ignorando o fato de que não era nada mais do que uma criatura efêmera; 6 [20], onde Menipo se apieda de Homero por ter louvado figuras que se tornaram completamente sem valor; ridiculariza os reis orientais que se julgavam deuses; e caçoa dos filósofos cujas doutrinas foram reveladas falsas pela própria morte (a dogmática interdição de se comerem favas, por Pitágoras; o vaidoso truque de Empédocles ao se jogar no Etna; ou a busca de Sócrates pela beleza); 7 [17], onde Menipo tenta convencer Tântalo de que, mesmo profundamente sequioso, entregar-se a tal sensação ou reclamar dela não faria nenhuma diferença (posto que ele já se encontra morto); 8 [26], onde Menipo ridiculariza

${ }^{15}$ Cumpre notar que praticamente não figuram personagens femininos nessa obra. A única representação desse tipo - ainda que breve - é a da deusa Perséfone (D. Mort. 28 [23], 3). Outras figuras femininas são mencionadas en passant, mas não têm papel ativo aí, ao contrário do que ocorre nos Diálogos das cortesãs, por exemplo. Para detalhes, cf. Bartley, 2005, p. 362.

${ }^{16}$ Como Bartley (2005, p. 362) nota: "Strongly visual descriptions exist mostly to highlight the characters of the dead, such as the description of the accoutrements that must be given up before boarding the ferry of Charon at Dialogue 20.2-11". Aqui pode ser interessante evocar o comentário de Bergson (1938, p. 52), segundo o qual: "Est comique tout incident qui appelle notre attention sur le physique d'une personne alors que le moral est en cause". Nesse sentido, cumpre notar, por exemplo, a menção à moleza típica dos crânios persas em D. Mort. 6 [20], 2. 
Quíron por não ter percebido que a morte seria tão monótona quanto a vida; 9 [28], onde Menipo caçoa de Tirésias por todas as histórias contadas por ele, uma vez que sua presença no submundo mostra que ele havia sido tão mortal quanto os demais; 10 [3], onde os profetas mortos, Trofônio e Anfíloco, são ridicularizados por defender que suas partes divinas ainda estariam profetizando na terra; 11 [16], onde Diógenes tenta convencer Héracles de que ele não poderia ter sido mortal e imortal ao mesmo tempo; 13 [13], onde Alexandre é repreendido por Diógenes por não ter aprendido a se dar conta da fragilidade dos dons da Fortuna; 14 [4], onde Hermes tenta cobrar a dívida de um Caronte empobrecido e incapaz de pagar por causa das baixas taxas de morte (numa possível alusão irônica ao período da Pax Romana); 20 [10], onde Menipo, acompanhado por Hermes e Caronte, caçoa dos poderosos, dos fortes e dos pensadores sofisticados, por se mostrarem relutantes em deixar suas posses mundanas antes de entrar no submundo; 21 [11], onde Crates e Diógenes desprezam as pessoas que desejaram obter em vida coisas inúteis (isto é, inúteis da perspectiva da morte e dos próprios cínicos); 22 [27], onde os três cínicos - Diógenes, Crates e Antístenes - caçoam das pessoas que viveram ignorando a inevitabilidade da morte; 29 [24], onde Diógenes ridiculariza o finado Mausolo por lamentar-se, lembrando e desejando sua vida pregressa na terra; 30 [25], onde a tentativa de Nireu de se assegurar como mais belo do que Tersites não tem sucesso, já que todos os mortos são parecidos entre si.

Essa maneira mais simples de ridicularizar a incapacidade de aceitar algo absolutamente inevitável - da perspectiva do submundo - é complementada por uma outra. No grupo de diálogos em que a herança é o principal tema, ${ }^{17}$ podemos encontrar um tipo diferente de zombaria, baseado principalmente em ressaltar a diferença entre a intenção da ação de alguém e o resultado efetivo da mesma. Podemos compreender esse tipo de riso também como um deboche da falta de autoconhecimento, na medida em que o erro é provocado pela ignorância das consequências das próprias ações. Os Diálogos dos mortos em que isso é mais destacado são os seguintes: 15 [5], onde Plutão instrui Hermes a deixar o rico Eucrates, ainda que já bem idoso, superar em vida todos os jovens que se enganam pensando que a herança do velho seria deles; 16 [6], onde Plutão repreende Térpsion por ter fingido ser amigo de alguém cuja morte ele desejava com todas as forças; 17 [7], onde Zenofante ridiculariza seu amigo Calidênides por ter tentado apressar a morte de seu já moribundo benfeitor; 18 [8], onde Cnêmon lamenta por ter arriscado sua vida a fim de aumentar sua própria fortuna; 19 [9], onde Polístratos fala zombeteiramente sobre todos os jovens que o amaram na esperança de herdar sua propriedade e terminaram de mãos vazias.

Deve ser notado que, apesar do aparente tom de moralidade, esse grupo de diálogos defende principalmente que se busque manter concordância entre as ações de alguém (e, mais até do que isso, os resultados de suas ações) e as próprias intenções ao agir. Pois quão estranha não seria a moralidade de um diálogo como o D. Mort. 18 [8], no qual se sugere que a queda do telhado de Cnêmon sobre a própria cabeça estaria conectada de alguma forma

\footnotetext{
${ }^{17}$ A leitura desses diálogos como um todo é sugerida pelo fato de serem dispostos em sequência idêntica tanto na tradição manuscrita dominante, tal como se encontra em $\Gamma$, quanto na ordem tradicional, além de compartilharem um mesmo tema principal, qual seja, o da herança e seus desdobramentos jurídicos.
} 
com a publicação de seu testamento (no qual deixava tudo para o "amigo" Hermolau). O que se ridiculariza aqui não é a busca por riquezas ${ }^{18}$ mas a inadequação da ação de Cnêmon no que diz respeito às próprias intenções, já que a principal consequência da publicação de seu testamento não foi se tornar mais rico (como ele esperava) e sim encontrar a morte mais cedo. ${ }^{19}$ Buscar riquezas não é algo condenável em si mesmo, já que Hermolau fez "como um lobo marinho, que junto com a isca engoliu também o anzol", vindo a ser praticamente louvado pela réplica final do interlocutor de Cnêmon, quando afirma: "E não é só isso. Ele pegou também o próprio pescador".

Assim sendo, acreditamos ter demonstrado que, nesses diálogos, a zombaria é principalmente construída como uma crítica da ignorância de si. Em outras palavras, acreditamos que o humor - tal como entendido de modo bastante simples e direto aqui em cada um dos diálogos mencionados é esboçado em defesa da máxima: "Conhece-te a ti mesmo". Devemos reconhecer, contudo, que mesmo onde essa asserção "positiva" é feita tão claramente quanto possível, seria possível defender a permanência de certo embaraço após a palavra final dos interlocutores. Isso pode ser devido principalmente à forma dialógica da obra de Luciano, se recorrermos aqui à teorização estabelecida por Bakhtin (1970) sobre "polifonia" e "dialogismo" como conceitos de teoria literária. Tal como notado por Relihan (1987, p. 192), Menipo "aparece como um tipo de indivíduo vaidoso cujo orgulho em suas próprias conquistas poderia ser objeto da crítica cínica presente nos Diálogos [...]". Seria possível defender que ele e (em nossa opinião) os outros cínicos também, ao se vangloriarem de seu autoconhecimento, por meio da tão frequente zombaria dos mortos incapazes de se conhecerem a si mesmos, agiriam de forma tão ridícula - da perspectiva do submundo - quanto os demais. Eles próprios estariam tentando minar o valor universal da igualdade dos mortos ao estabelecer o princípio do autoconhecimento como a medida para seu comportamento. Da perspectiva dos cínicos, que à primeira vista pareceriam os heróis desses diálogos, ${ }^{20}$ esse princípio seria verdadeiro e poderia ser usado para fundar o humor com relação à ignorância de si demonstrada pelos demais. O que eles próprios parecem ignorar, contudo, é que a morte torna todos iguais - até mesmo os cínicos - e que sua sabedoria só poderia estar em constatar que sua sabedoria não faz tanta diferença assim. ${ }^{21}$

\footnotetext{
${ }^{18}$ Segundo Brandão (1996, p. 20), a atitude de Luciano com relação à riqueza não é revolucionária. Ele parece criticá-la, por meio do riso, mas jamais condená-la. Além disso, não chega a louvar a pobreza. ${ }^{19}$ Isso é tornado evidente pelo zombeteiro comentário do interlocutor de Cnêmon ao fim desse diálogo,

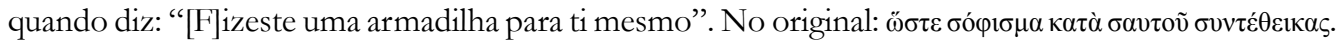
${ }^{20}$ Nos "diálogos de zombaria", a aparente determinação de um lado "certo" - em detrimento de um "errado" - parece ter pego Relihan (1987, p. 192) em uma das armadilhas de Luciano, já que o estudioso defende a dimensão heroica da personagem de Menipo nesse conjunto de textos. Em nossa opinião, nem mesmo nos "diálogos de zombaria" haveria um lado "certo", mas lados mais ou menos risíveis. ${ }^{21}$ Aqui estamos apenas ampliando o escopo da asserção de Relihan (1987, p. 202) no que diz respeito à inutilidade da sabedoria de Menipo.
} 
Essas fissuras internas ao discurso cínico, cuja perspectiva parece predominar ao longo dos Diálogos dos mortos, poderia ser a responsável por gerar o embaraço já mencionado, mesmo no interior de uma leitura mais simples e direta do riso gerado por eles. ${ }^{22}$ Se mudamos a perspectiva, como a forma dialógica dessa obra nos convida a fazer, todos os personagens que criticam os outros por não se conhecerem a si mesmos aparecem também como ridículos em sua vangloriosa tentativa de se diferenciarem, já que todos estão mortos e não pode haver diferenciação entre eles. Sua vaidade é uma forma de ignorância de si tão grande quanto as formas de ignorância de si ridicularizadas por eles. Nesse sentido, o princípio do "conhecete a ti mesmo" apareceria como a medida para os cínicos ridicularizarem o comportamento dos outros e, simultaneamente (ainda que de uma perspectiva diversa), para serem levados a agir de forma ridícula ao fazerem isso. ${ }^{23}$

\section{IV}

Baseando nossa análise na relação estabelecida por Platão, entre o ridículo e a ignorância, sugerimos uma maneira de interpretar a maior parte dos Diálogos dos mortos: de uma perspectiva principal, a favor dos cínicos, já que a máxima "conhece-te a ti mesmo" e a valorização do autoconhecimento aparecem como a forma mais simples e direta do cômico nessa obra; contudo, de uma perspectiva alternativa, contra os cínicos, posto que subjaz a possibilidade subsidiária de que a vaidade desses sábios defuntos seja colocada ela própria como um possível objeto de ridículo. Para além dessa análise geral, contudo, afirmamos que, levando em conta as atitudes que certos personagens apresentavam em relação aos outros, poderíamos encontrar em outros diálogos que também compõem essa obra uma segunda tendência principal - além da que estava relacionada à zombaria -, qual seja, a de uma disputa agônica, na qual um tour de force é estabelecido entre os interlocutores. ${ }^{24}$

Nos diálogos em que essa tendência é a mais proeminente, uma tensão entre os personagens parece ainda mais amplificada. Esse efeito se deve à falta do que pareceria uma determinação a priori do lado "certo" em detrimento de um "errado". Todos os personagens recebem voz para apresentar seus argumentos a fim de se engajar em uma espécie de

\footnotetext{
${ }^{22} \mathrm{O}$ tratamento que Halliwell oferece à obra de Luciano, no interior do quadro ligado ao riso na literatura grega, leva em conta apenas essa forma unilateral de compreendê-la (isto é, assumindo a perspectiva dos personagens cínicos como a "correta"). Sua conclusão, ainda que sugira a possibilidade de se rir simultaneamente - nos Diálogos dos mortos - tanto da vida quanto da morte, não chama a atenção para o ridículo das pessoas que ficam rindo o tempo todo das outras. Cf. Halliwell, 2008, p. 470-71. ${ }^{23}$ Pode ser interessante evocar aqui as palavras de Bakhtin sobre um discurso monológico a fim de sugerir as implicações que isso teria sobre o discurso dialógico de Luciano: "Dans un monde du monologue tertium non datur: la pensée est ou bien affirmée ou bien niée, sinon elle cesse tout simplement d'être une pensée ayant sa pleine signification." (Bakhtine, 1970, p. 94). O oposto é, então, verdade sobre a "pensée" contida nesse luciânico "monde du dialogue": suas relações de força não são tão unívocas quanto se poderia a princípio ser levado a imaginar.

${ }^{24}$ Nesse sentido, cumpre lembrar que Brandão (2001, p. 229) fala do diálogo como um espaço agonístico em que uma crise pode ser mimetizada e exibida.
} 
competição retórica que é aí representada. Os diálogos agônicos são os seguintes: 12 [14], onde Filipe repreende Alexandre por ter acreditado (e talvez continuar acreditando) em sua ascendência divina; 23 [29], onde Agamêmnon tenta convencer Ájax a perdoar Odisseu; 24 [30], onde Sóstrato defende sua inocência baseado no argumento de que não poderia ser culpado por algo já determinado pela Fortuna; 25 [12], onde Aníbal disputa com Alexandre pelo primeiro lugar como líder militar; 26 [15], onde Antíloco critica Aquiles por suas infames palavras para Odisseu, tal como a Odisseia (11.489-91) representa; 27 [19], onde Éaco repreende Protesilau por culpar alguém além dele mesmo (ou, como acaba acontecendo, a própria Fortuna) como a causa de seus infortúnios; 28 [23], onde Protesilau implora a Plutão e a Perséfone para ser enviado de volta à vida por um único dia, a fim de passá-lo com sua inesquecível mulher.

É preciso notar que alguns motivos já mencionados recebem um tratamento análogo nesses sete diálogos, como, por exemplo, a necessidade de aceitar algo inevitável, a representação do esquecimento como um medicamento no post-mortem e, é claro, a importância de se conhecer a si mesmo. A diferença desses diálogos, contudo, é que embora apresentem um tour de force retórico - a igualdade inicial dos argumentos em que os personagens parecem exibir sua disputa é minada ao longo do diálogo. Isso pode ser devido principalmente ao fato de que alguns argumentos realmente parecem levar em conta o princípio do autoconhecimento no que diz respeito às circunstâncias presentes. Há até quem desenvolva essa compreensão ao longo do próprio diálogo, como no caso de Protesilau, que, por meio do diálogo, se dá conta da inevitabilidade da própria fortuna (D. Mort. 27 [19]). A igualdade aparente entre os adversários retóricos parece ser destruída pelo efetivo reconhecimento que um dos lados apresenta acerca de sua condição atual.

Nesse sentido, a aparente igualdade de partida entre os interlocutores desses diálogos vem a ser efetivamente minada pela atitude coerente que um deles assume em sua demonstração de autoconhecimento perante as circunstâncias em que eles se encontram. Essa é a razão para que Filipe repreenda tão firmemente as aspirações de seu filho - morto e, portanto, desde sempre mortal - em se comparar aos deuses imortais. Essa também é a razão para que Ájax possa afirmar tão inflexivelmente seu ódio por Odisseu, apesar de seu respeito recentemente adquirido por Atena; ou para que Sóstrato venha a convencer Minos acerca de sua própria inocência (apesar dos feitos criminosos de sua vida); ou para que Cipião consiga persuadir Minos sobre a grandeza de Alexandre com relação a Aníbal; ou para que Antíloco venha a apresentar uma atitude mais conveniente do que a de Aquiles (com relação à atual condição deles como pessoas mortas, sem marcas de distinção); ou para que Protesilau seja levado a descobrir que, ao invés de reclamar de sua Fortuna, poderia tentar alterá-la. ${ }^{25}$ Além disso, todos esses diálogos têm características comuns: um relato positivo

\footnotetext{
${ }^{25}$ Essa interpretação unitária de D. Mort. 27 [19] e 28 [23] é sugerida por sua disposição concatenada (em sequência imediata segundo a ordem encontrada em $\Gamma$ ou tendo três diálogos entre eles, na ordem tradicional), bem como por sua coincidência de assunto e de protagonista.
} 
do princípio "conhece-te a ti mesmo"; 26 a presença de personagens épicos; a ausência de cínicos; um tipo de humor bem menos evidente e uma quase total ausência de zombaria. Essas evidências levam-nos a considerar que eles são estruturalmente diversos dos outros diálogos anteriormente mencionados, formando um segundo grupo no interior dos Diálogos dos mortos.

\section{V}

Tendo analisado sucintamente todas as trinta peças que compõem os Diálogos dos mortos, esperamos ter esclarecido as relações entre os principais traços cômicos dessa obra e uma compreensão filosófica do mundo. ${ }^{27}$ Pretendemos concluir em breve, mas antes gostaríamos de fazer um rápido excurso para levar em consideração a ausência de uma voz notável nessa obra: a de Odisseu. ${ }^{28}$ Mesmo que seja complicado sugerir o significado de uma ausência - ainda mais para o caso de obras da Antiguidade, cuja dimensão de completude raramente pode ser afirmada com certeza -, pensamos que o silêncio de Odisseu nos Diálogos dos mortos seja bastante importante. Luciano parece aceitar a versão da katábasis relatada pelo filho de Laertes na Odisseia, como certas alusões nos diálogos entre Ájax e Agamêmnon (D. Mort. 23 [29]), por um lado, e entre Aquiles e Antíloco (D. Mort. 26 [15]), por outro, tornam evidente. Ainda que Tirésias seja representado como um falso profeta e um mentiroso em D. Mort. 9 [28], essa representação é feita por Menipo, e sua voz, como já vimos, tem que ser relativizada no interior dessa obra. Em todo caso, parece que Luciano não deforma o relato homérico acerca do submundo, mas antes o performa, desdobrando as consequências cômicas que uma tentativa de levá-los ao pé da letra poderia ter. É possível evocar - além dos três diálogos já mencionados - também o D. Mort. 11 [16], no qual a descrição física de Héracles no submundo não é radicalmente diversa daquela que é feita por Odisseu na corte de Alcínoo, ${ }^{29}$ mas apenas as especulações sobre o significado religioso dela diferem de forma profundamente cômica: a sombra de Héracles é localizada por Odisseu no submundo (e esse dado é retomado por Luciano), mas a problematização cômica se dá justamente no modo como isso teria que se arranjar com o relato tradicional sobre a apoteose do herói no monte Eta.

\footnotetext{
${ }^{26}$ Filipe chega até a exteriorizá-lo (em D. Mort. 12 [14], 6): "Não tens vergonha, Alexandre? Tu não desistirás de tua vaidade, não te conhecerás a ti mesmo, nem compreenderás que já está morto?”. No

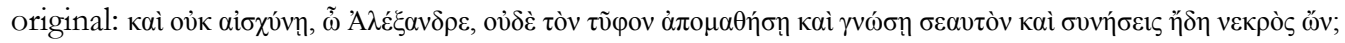
${ }^{27}$ Para uma visão contrária sobre a relação de Luciano com a filosofia, cf. Bompaire, 1958, p. 125-7. ${ }^{28} \mathrm{Tal}$ como notado por Möllendorf (2010, p. 76, n. 7): "Ebenso mag von Interesse sein, dass beispielsweise eine a priori für eine Sprecherolle prädestinierte Gestalt wie Odysseus fehlt [...]." Embora Odisseu não tenha fala na obra, ele é visto por Menipo entre os "melhores dos gregos" (áristoi tôn Hellénon), no D. Mort. 6 [20], 1.

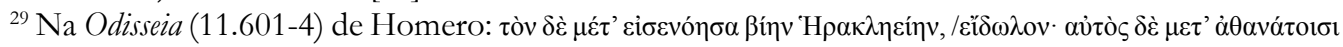

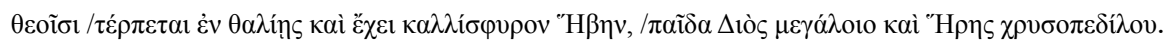


Se nossa suposição sobre a concordância de Luciano com a katábasis de Odisseu - conforme o relato homérico - estiver correta, esse personagem seria dotado de uma perspectiva vantajosa que praticamente nenhum dos demais personagens representados nos Diálogos dos mortos teria: pois ele saberia ainda em vida o que o esperava depois da morte. Ele é presenteado com a vantagem que Aquiles (tanto em Od. 11.489-91 quanto em D. Mort. 26 $[15], 2)$ reclama não ter tido quando fez sua escolha por uma vida breve, embora honrada, em vez de uma longa e obscura existência como lavrador do campo. Odisseu já sabe quão miserável é o post-mortem quando faz sua opção por um destino mortal - ao optar pelo retorno a Ítaca -, ao invés de permanecer com Calipso na ilha de Ogígia. ${ }^{30}$

Nesse sentido, vale a pena evocar sua caracterização no proêmio da Odisseia como um homem que viu as cidades de muitas pessoas, tendo aprendido suas mentes. ${ }^{31}$ Em vista da relação já sugerida nos Diálogos dos mortos entre o ridículo e a ignorância, Odisseu seria potencialmente o menos ridículo de todos os personagens gregos mortais - na versão homérica - à disposição de Luciano. A menos que o relato de Odisseu na corte dos feácios devesse ser totalmente rejeitado como mentiroso (tal como é afirmado em outro livro de Luciano, Das narrativas verdadeiras, ${ }^{32}$ no qual a representação de Odisseu vem inclusive a se revelar fundamentalmente diversa e preponderantemente cômica), o autoconhecimento adquirido pelo herói por meio de sua katábasis dificilmente daria espaço para fazer dele um bom objeto de ridículo. Qualquer decisão tomada por ele teria sido com uma consciência extrema sobre a miserável condição humana após a morte. ${ }^{33}$

\section{VI}

Depois desse breve excurso, dedicado à tentativa de explicar o silêncio de Odisseu (ou, pelo menos, especular sobre as razões de Luciano para tal), voltamos a nosso argumento principal com o objetivo de concluir o presente texto. Acreditamos ter sugerido de que modo a disputa de certos princípios pode ser entrevista no cerne de todos os Diálogos dos mortos. Se, por um lado, a igualdade (isotimía) do submundo é frequentemente defendida e até usada como um recurso para ridicularizar pessoas que tentem miná-la, por outro, o princípio do

\footnotetext{
${ }^{30}$ Segundo Brandão (2001, p. 261), a experiência de Odisseu da alteridade é um elemento funcional importante para seu retorno. É possível afirmar que ele opta por permanecer com o que é mais característico dele próprio (tà oikeía) de um modo tão consciente apenas por ter realmente experimentado a alteridade (tà exotiká).

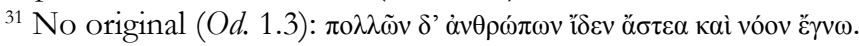

${ }^{32}$ Logo no início dessa obra, as histórias de Odisseu são consideradas charlatanice pelo narrador ( $V H$

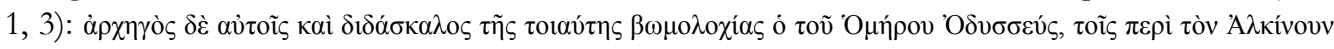

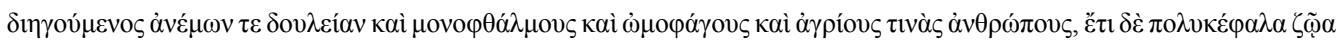

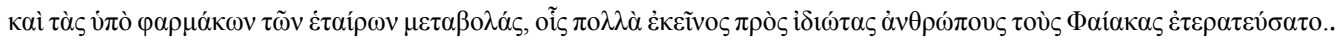
${ }^{33}$ Acreditamos que isso seja um dos fatores determinantes para a retomada da figura de Odisseu por parte de Platão, Luciano e Joyce, em momentos importantes de suas obras (tal como sugerido por nós em uma nota anterior).
} 
autoconhecimento é abertamente exibido como a única forma de lidar apropriadamente com qualquer circunstância (inclusive, nesse caso, com a própria morte). Com relação a essa igualdade, os cínicos riem de todos que tentam colocá-la de lado - por meio da recordação de sua situação mundana ou reclamando-a -, mas podem tornar-se igualmente risíveis ao vangloriarem-se e tentarem diferenciar-se dos demais por meio da posse de um autoconhecimento profundo e abrangente. $\mathrm{O}$ que eles parecem ignorar é que, ao rir dos mortos que se ignoram a si próprios, eles agem ridiculamente devido à ignorância de que a igualdade do submundo não poderia ser solapada por nada (nem mesmo por um "novo" princípio como o do autoconhecimento). A asserção platônica sobre o ridículo - tal como está relacionada a uma ignorância de si desprovida de poder - é, portanto, uma das fontes primordiais de riso exibidas por Luciano, independentemente da perspectiva por que se tomam os personagens.

Esse mesmo critério é importante para se compreender por que alguns diálogos não apresentam tais traços risíveis, mas antes exibem algumas considerações sérias sobre a natureza da vida e da morte. Nos diálogos em que um tour de force retórico acontece, a aparente igualdade inicial dos adversários é na verdade solapada pelos argumentos da parte que se mostra capaz de levar em conta suas circunstâncias presentes, sugerindo a necessidade de coerência entre atitude (práxis) e autoconhecimento (lógos).

Para colocar de forma esquemática: nos diálogos de zombaria, as reivindicações de superioridade por parte dos defuntos ignorantes são colocadas de lado pelo princípio da igualdade (e, aceitando a ideia de que os próprios cínicos se mostram vaidosos e, portanto, também ridículos, suas reivindicações de superioridade com base no autoconhecimento seriam colocadas de lado também pelo princípio geral da igualdade dos mortos); já nos diálogos de disputa retórica, a aparente igualdade de base é colocada de lado pelo princípio do autoconhecimento. Essa é a razão pela qual nos Diálogos dos mortos os argumentos parecem ser minados de seu próprio interior, levando a apreciações tão contraditórias por parte de seus estudiosos.

Nossas considerações poderiam ser tomadas como se buscassem concluir que uma negatividade absoluta subjazesse à obra de Luciano, tornando impossível determinar com precisão os objetos efetivos de seu riso. ${ }^{34}$ Contudo, muito pelo contrário, acreditamos que uma mensagem positiva - ainda que pareça dúbia em sua aplicabilidade - seja claramente definida ao longo desses diálogos, qual seja, uma possibilidade de equilíbrio entre seus dois princípios mais importantes: o de igualdade (isotimía) e o de autoconhecimento (gnôthi sautón). Essa interpretação inscreve os Diálogos dos mortos dentro de um projeto mais geral de Luciano, responsável por escrutinar a sociedade e a cultura de seu tempo por meio de uma reflexão crítica que expõe ao ridículo suas falácias, como o fato de muitos se deixarem guiar

\footnotetext{
${ }^{34}$ Tal como é sugerido por Relihan (1987, p. 204), quando - falando dos Diálogos dos mortos - defende que: "These fantasies are in themselves quite arresting, but this is self-destructive fantasy".
} 
por medo e esperança ${ }^{35}$ ignorando valores realmente importantes como os já mencionados, autoconhecimento e igualdade.

Nesse sentido, acreditamos que a obra de Luciano - embora tenha sido composta na antiguidade e, portanto, não esteja contemplada por aquilo que Derrida (2015, p. 58) resguarda como prerrogativa da institucionalização da literatura na modernidade - seja dotada de uma inegável função crítico-política perante a própria sociedade. A ficção de Luciano, valendo-se da prerrogativa literária de "dizer tudo" - e acreditamos dizê-lo sem anacronismo -, posiciona-se criticamente perante as questões e os problemas de seu próprio tempo. Para o caso dos Diálogos dos mortos, a possibilidade de encontrar um equilíbrio entre o autoconhecimento e a igualdade tem implicações tanto para os mortos representados ficcionalmente na obra, quanto para os mortais que os presenciam por meio da leitura (isto é, tanto para os contemporâneos de Luciano quanto para seus leitores pósteros): por um lado, os mortais precisam reconhecer a inevitabilidade de suas mortes, vindo a pautar suas vidas por esse conhecimento das coisas derradeiras, enquanto, por outro, os mortos precisam reconhecer quão inútil é falar, a fim de que aprendam a nada dizer e a tudo suportar... ${ }^{36}$

\section{REFERÊNCIAS}

ANDRIES, Lise. Querelles et dialogues des morts au XVIIIe siècle. Littératures classiques, n. 81, v. 2, p. 131-46, 2013.

ARAÚJO, Nabil. O postulado do "realismo formal" no Brasil: da tautologia nacional à profissão de fé. O eixo e a roda: Revista de Literatura Brasileira, v. 24, n. 2, p. 139-56, 2015 a.

ARAÚJO, Nabil. Do romance: entre a "lei do gênero" e a "lei do gênio". Eutomia: Revista de Literatura e Linguistica, v. 16, n. 1, p. 118-36, 2015b.

AVELLAR, Júlia Batista Castilho de. Uma "Literatura da Teoria": o romance na Antiguidade Clássica e no Romantismo Alemão. Palestra proferida durante a IX Semana da Letras e VIII SPLIT (Semana de Pós-graduação em Letras: Estudos Literários), na FALE/UFMG (Belo Horizonte), em 23 out. 2018.

BAKHTINE, Mikhaiil. Problèmes de la Poétique de Dostö̈eski. Traduit par Guy Verret. Lausanne: Éditions l'Âge d'Homme, 1970.

BALDWIN, Barry. Lucian as Social Satirist. The Classical Quarterly, v. 11, n. 2, p. 199-208, 1961.

\footnotetext{
${ }^{35} \mathrm{~A}$ crítica ao medo e à esperança como enganos da vida humana aparece volta e meia nas obras do corpus lucianeum, como, por exemplo, em: Alex. 8; Cat. 11; Cont. 15.

${ }^{36}$ À guisa de encerramento com um tom filosófico, parafraseamos as últimas palavras de Antíloco para Aquiles (em D. Mort. 26 [15], 4), onde ele parece destilar a derradeira possibilidade de sabedoria para os mortos: silêncio total. Tentamos sugerir o sentido do silêncio de Odisseu nessa mesma direção.

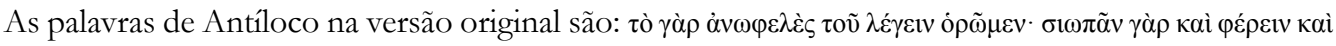

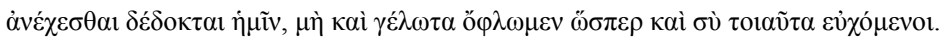


BARTLEY, Adam. Techniques of Composition in Lucian's Minor Dialogues. Hermes, v. 133, n. 3, p. 358-67, 2005.

BERGSON, Henri. Le rire. Essai sur la signification du comique. Paris: Félix Alcan, 1938.

BOMPAIRE, Jacques. Lucien Écrivain. Imitation et création. Paris: Boccard, 1958.

BRANDÃO, Jacyntho Lins. Diálogos dos mortos sobre os vivos. In: LUCIANO. Diálogos dos mortos. Tradução e notas de Maria Celeste Consolin Dezotti. São Paulo: Hucitec, 1996, p. $11-44$.

BRANDÃO, Jacyntho Lins. A invenção do romance. Narrativa e mimese no romance grego. Brasília: UnB, 2005.

BRANDÃO, Jacyntho Lins. A Poética do Hipocentauro. Literatura, sociedade e discurso ficcional em Luciano de Samósata. Belo Horizonte: UFMG, 2001.

BRANHAM, Robert B. Unruly eloquence. Lucian and the comedy of traditions. Cambridge: Cambridge University Press, 1989.

HALLIWELL, Stephen. Greek laughter. A study of cultural psychology from Homer to early Christianity. Cambridge: Cambridge University Press, 2008.

HOMER. The Odyssey. With an English Translation by A. T. Murray. Cambridge \& London: William Heinemann \& Harvard University Press, 1919. 2 v.

LACOUE-LABARTHE, Philippe; NANCY, Jean-Luc. L'Absolu littéraire. Théorie de la littérature du romantisme allemand. Paris: Éditions du Seuil, 1978.

LUCIAN. Dialogues of the Dead. In: . Complete Works. With an English translation by M. D. Macleod. Cambridge: William Heinemann \& Harvard University Press, 1961. v. 7.

LUCIAN. Verae Historiae. In: . Lucian's Works. With an English Translation by A. M. Harmon. Cambridge: William Heinemann \& Harvard University Press, 1913.

LUCIANO. Diálogos dos mortos. Trad. Henrique G. Murachco. São Paulo: Palas Athena/USP, 2007.

LUCIANO. Luciano IV. Trad. Custódio Magueijo. Coimbra: Imprensa da Universidade de Coimbra, 2013.

MEDEIROS, Constantino Luz de. Invenção da modernidade literária. Friedrich Schlegel e o romantismo alemão. São Paulo: Iluminuras, 2018.

MIRANDA, Jorge Cunha Conrado de. O Mito de Er, apresentado na República de Platão, como chave para a leitura do romance Ulysses, de James Joyce. Comunicação proferida durante o XX Congresso da SBEC: Público e privado na Antiguidade, na UFOP (Mariana), em 20 nov. 2015. 
MÖLLENDORF, Peter von. Lukians Dialogkorpora: Ein äethetisches Experiment. In: HEMPFER, Klaus; TRANINGER, Anita (Hrsg.): Der Dialog im Diskursfeld seiner Zeit: Von der Antike bis zur Aufklärung. Stuttgart: Franz Steiner Verlag, 2010, p. 75-94.

PLATÃO. Filebo. Texto grego por John Burnet; trad. Fernando Muniz. Rio de Janeiro: PUCRio; São Paulo: Loyola, 2012.

PLATÃO. A República de Platão. 2. ed. Organização e tradução de Jacó Guinsburg; notas de Daniel Rossi Nunes Lopes. São Paulo: Perspectiva, 2014. (Obras, 1).

PLATO. Platonis Opera. Ed. John Burnet. Oxford: Oxford University Press, 1903.

RELIHAN, Joel C. Vainglorious Menippus in Lucian's "Dialogues of the Dead". Illinois Classical Studies, v. 12, n. 1, p. 185-206, 1987.

SILVA, Rafael. The laughter within the Dialogues of the dead. Revele, n. 8, p. 95-109, 2015.

WATT, Ian. A ascensão do romance. Estudos sobre Defoe, Richardson e Fielding. São Paulo: Cia. das Letras, 2007. 